\title{
Genetic Transformation in Methylobacterium organophilum
}

\author{
By MARY O'CONNOR, ANN WOPAT AND R. S. HANSON \\ Department of Bacteriology, University of Wisconsin, Madison, \\ Wisconsin 53706, U.S.A.
}

(Received I5 June 1976; revised 12 August 1976)

\section{SUMMAR Y}

Several mutants have been isolated from the facultative methylotroph, Methylobacterium organophilum, using either $N$-methyl- $N^{\prime}$-nitro- $N$-nitrosoguanidine or ultraviolet light as mutagens. One of these isolates, a glutamate auxotroph lacking isocitrate dehydrogenase, has been transformed to prototrophy, using wild-type DNA, at a frequency of $0.5 \%$. Competence and DNA uptake occur only in cultures which are near the end of exponential growth, and maximal transformation requires a DNA concentration of $100 \mu \mathrm{g} \mathrm{ml}^{-1}$.

\section{INTRODUCTION}

Methylobacterium organophilum is a facultative methylotroph. It can utilize $\mathrm{C}_{1}$ compounds as sole carbon and energy sources but unlike all previously isolated methane oxidizers it can also grow on more complex organic substrates (Patt et al., 1974). The isolation and characterization of this organism has greatly increased the potential for physiological studies of sterol synthesis (T. E. Patt, unpublished results), membrane biogenesis and $\mathrm{C}_{1}$ metabolism. However, these studies can only be adequately supported with the benefit of genetic analysis. This depends on the availability of mutants, but mutants of methane oxidizers have been difficult to obtain for reasons that are not clear (Williams \& Bainbridge, I97I).

\section{METHODS}

Organism. Methylobacterium organophilum (ATCC27886, Patt et al., 1974) was used in all experiments.

Media and growth conditions. The modified nitrate mineral salts medium (NMS) previously described (Patt, Cole \& Hanson, 1976) was used for all studies. All supplements except methanol were dissolved in distilled water, sterilized separately and added directly to the growth medium at the following concentrations (w/v): succinate, $0 \cdot 1 \%$; Casamino acids, $0.05 \%$; L-glutamate, $0.05 \%$ (unless stated otherwise). Methanol $(96 \%, v / v)$ was filtersterilized and added separately to the growth medium at a concentration of $0.5 \%(\mathrm{v} / \mathrm{v})$.

All cultures were incubated at $30^{\circ} \mathrm{C}$ with methanol as the carbon source unless stated otherwise. Liquid cultures were incubated on rotary shakers. The large batches of cells used for DNA isolation were grown and harvested as described previously (O'Connor \& Hanson, I975).

Survival curves

Ultraviolet (u.v.) light. An exponential-phase culture $(40 \mathrm{ml})$ was harvested and resuspended in $2 \mathrm{ml}$ sterile NMS medium. The suspension was placed in a sterile Petri dish in the dark and exposed to u.v. light (Westinghouse Sterilamp, no. 782L-30) at a distance of $40 \mathrm{~cm}$. At intervals, samples were withdrawn and plated on NMS/methanol agar. 
$N$-methyl- $N^{\prime}$-nitro- $N$-nitrosoguanidine $(N T G)$. An exponential-phase culture $(40 \mathrm{ml})$ was centrifuged, washed and resuspended in $6 \mathrm{ml} \mathrm{NMS} /$ methanol medium. The suspension was divided into I $\mathrm{ml}$ samples and different amounts of NTG were added to each. The samples were incubated in test-tubes on a shaker for $2 \mathrm{~h}$. From each sample, $0.5 \mathrm{ml}$ was filtered on a Millipore filter (HAWG, $0.45 \mu \mathrm{m}$ pore size) and organisms were washed with Io $\mathrm{ml}$ distilled water, resuspended in $0.5 \mathrm{ml}$ sterile NMS medium and plated on NMS/methanol agar.

Penicillin. A late exponential-phase culture was harvested, washed twice with NMS medium, and resuspended in NMS/methanol plus $7.5 \%(\mathrm{w} / \mathrm{v})$ polyethylene glycol plus $0.25 \%(\mathrm{w} / \mathrm{v}) \mathrm{MgSO}_{4} \cdot 7 \mathrm{H}_{2} \mathrm{O}$. The suspension was divided into five parts and one sample was plated on NMS/methanol agar. Different amounts of penicillin were added to the other four samples and the flasks were incubated for $20 \mathrm{~h}$. Penicillinase $\left(12.5 \mu \mathrm{g} \mathrm{ml}^{-1}\right.$; Calbiochem) was added and incubation was continued for $\mathrm{I} h$. The bacteria were then washed and samples were spread on the surface of NMS/methanol agar plates.

DNA isolation. Frozen cells were thawed, washed twice in $0.05 \mathrm{M}$-Tris/0.02 M-EDTA (TE) buffer, $\mathrm{pH} 8{ }^{\circ}$, and resuspended in $90 \mathrm{ml} \mathrm{TE}$ buffer per $5^{\circ} \mathrm{og}$ wet wt cells. The solution was made up to $\mathrm{I} \%(\mathrm{w} / \mathrm{v})$ in sodium lauryl sulphate and heated to $60^{\circ} \mathrm{C}$ for $30 \mathrm{~min}$. Ten $\mathrm{ml}$ Streptomyces griseus type VI protease $\left(5 \mathrm{mg} \mathrm{ml}^{-1}\right.$; Sigma), previously heat-treated at $80^{\circ} \mathrm{C}$ for $10 \mathrm{~min}$, was added and incubation was continued at $60^{\circ} \mathrm{C}$ for $2 \mathrm{~h}$ or until lysis was complete. "Water-saturated phenol ( $0.5 \mathrm{vol}$.) was added and the solution was shaken for $15 \mathrm{~min}$. The solution was then centrifuged and the aqueous layer removed. RNAase A and RNAase $T_{1}$ (Sigma), previously heated in boiling water for $5 \mathrm{~min}$, were added to a final concentration of $100 \mu \mathrm{g}$ and 30 units $\mathrm{ml}^{-1}$, respectively, and the solution was incubated at $37^{\circ} \mathrm{C}$ for $\mathrm{r} \mathrm{h}$. The DNA was precipitated with 2 vols cold $95 \%$ ethanol, and resuspended in sterile $0.1 \times$ standard saline citrate buffer (SSC: 0.15 M-sodium chloride/0.015 M-sodium citrate, $\mathrm{pH} 7 \cdot 3$ ). DNA preparations were kept frozen in $0.5 \mathrm{ml}$ quantities at $-20^{\circ} \mathrm{C}$. DNA concentrations were estimated using the diphenylamine assay described by Burton (1956).

Sheared DNA was prepared by vortexing the sample for $30 \mathrm{~s}$ at high speed, then forcing it through a $26 \frac{1}{2}$ gauge needle five times. This greatly diminished the viscosity of the DNA solution.

Determination of the molecular weight of DNA. The average size of sheared and unsheared DNA preparations was estimated using an agarose gel electrophoresis technique similar to that of Helling, Goodman \& Boyer (1974). Lambda DNA, treated with EcoRI nuclease, was used as a standard. Agarose was obtained from MCK Biomedical (Rockland, Maine, U.S.A.).

\section{Mutant isolation.}

Mutagenesis. (i) U.v. light. Bacteria were prepared and exposed to u.v. light for $3 \mathrm{~min}$ as described for the survival curve. The mutagenized bacteria were transferred to a stirred flask of supplemented medium and incubated for 8 to $12 \mathrm{~h}$ at room temperature in the dark.

(ii) NTG. A culture $(40 \mathrm{ml})$ was treated as described for the NTG survival curve. A sample ( $\mathrm{I} \mathrm{ml}$ ) was incubated on a shaker for $25 \mathrm{~min}$, I ml filter-sterilized NTG $(4 \mathrm{mg}$ $\mathrm{ml}^{-1}$ ) was added and incubation was continued for $2 \mathrm{~h}$. The bacteria were collected on a Millipore filter and washed throughly with NMS medium. The filter was placed in $40 \mathrm{ml}$ supplemented medium and incubated on a shaker overnight.

Penicillin selection. Mutagenized, overnight cultures were washed twice with sterile NMS media and resuspended in nitrogen-free NMS medium at a density of $10^{6}$ viable units $\mathrm{ml}^{-1}$. 
After to $\mathrm{h}$ incubation on a shaker, the culture was transferred to minimal NMS medium containing $7.5 \%$ polyethylene glycol, $0.25 \% \mathrm{MgSO}_{4} \cdot 7 \mathrm{H}_{2} \mathrm{O}$ and 500 units penicillin $\mathrm{ml}^{-1}$ (Sigma) and was incubated for a further $20 \mathrm{~h}$. Penicillinase was then added to a final concentration of $12.5 \mu \mathrm{g} \mathrm{ml}^{-1}$, and incubation was continued for another hour.

Mutant selection. Three types of mutants were selected: amino-acid auxotrophs, drugresistant mutants, and mutants unable to grow on methanol but capable of growth on succinate (methanol- mutants). The mutagenized bacteria from the penicillin selection treatment were washed and plated on supplemented media. For the drug-resistant mutants, colonies which grew on NMS/methanol medium plus streptomycin $\left(50 \mu \mathrm{g} \mathrm{ml}^{-1}\right)$, erythrocin (500 $\left.\mu \mathrm{g} \mathrm{ml}^{-1}\right)$ or rifampicin $\left(50 \mu \mathrm{g} \mathrm{ml}^{-1}\right)$, were picked and streaked for isolation. For the auxotrophs, colonies on the supplemented plates (NMS/methanol medium plus $0.05 \%$ Casamino acids) were replica-plated on to unsupplemented media (NMS/methanol) and those which grew on the supplemented media but not on the unsupplemented were purified by streaking on supplemented media. Methanol- mutants were selected as colonies which grew on NMS plus succinate agar but would not grow when replicated on to NMS/methanol agar.

Preparation of extracts. Late exponential-phase cultures were harvested, washed and resuspended in TMME buffer (Hanson \& Cox, 1967) using $2 \mathrm{ml}$ buffer per $\mathrm{g}$ cells. The bacteria were sonicated at maximum intensity for $3 \mathrm{~min}$ (Bronwill Biosonik Sonifier, Bronwill Scientific, Rochester, New York, U.S.A.), and centrifuged at $20000 \mathrm{~g}$ for $20 \mathrm{~min}$. The soluble fraction was assayed for isocitrate dehydrogenase activity. Protein was estimated by the method of Lowry et al. (195I).

Isocitrate dehydrogenase assay. Isocitrate dehydrogenase (EC. I.I.I.42) was assayed by the method of Hanson \& $\mathrm{Cox}$ (1967). NADP+ (3 mM) was incubated in a cuvette with cellfree extract for I min to ensure there was no $\mathrm{NADP}^{+}$reduction in the absence of substrate. Isocitrate ( $1.5 \mathrm{~mm}$ final concentration) was added and the activity was followed by measuring the change in $E_{340}$ in a Gilford 2000 Spectrophotometer (Gilford Laboratories Instruments, Oberlin, Ohio, U.S.A.).

Growth response of mutant $3 \mathrm{~A}$ to L-glutamate. Tubes containing $3 \mathrm{ml} \mathrm{NMS} / \mathrm{methanol}$ medium and different amounts of L-glutamate, were incoulated with isolate $3 \mathrm{~A}$ to give an initial absorbance of about 0.15 at $600 \mathrm{~nm}$ and were incubated with shaking. The absorbance of samples taken from the tubes was determined at $24 \mathrm{~h}$ intervals.

\section{Transformation}

DNA present throughout growth. For routine experiments, DNA from wild-type bacteria ( $100 \mu \mathrm{g} \mathrm{ml}^{-1}$ ) was added to inoculated cultures which were allowed to grow to stationary phase. The bacteria were washed and plated on selective (NMS/methanol) and non-selective (NMS/methanol plus Casamino acids) media. In some cases, the bacteria were regrown for two generations in the presence of glutamate before plating.

For all experiments, control cultures were included containing sterile $\mathrm{O} \cdot \mathrm{I} \times \mathrm{SSC}$ in place of DNA, or DNA which had been treated with $40 \mu \mathrm{g} \mathrm{DNAase} \mathrm{ml}^{-1}$ for $30 \mathrm{~min}$ before addition to the culture.

Competence and DNA uptake determinations. Triplicate I $\mathrm{ml}$ samples were taken from a culture at various times during growth, measured using a Klett-Summerson colorimeter (Klett Manufacturing Co., New York, U.S.A.). Two of the samples were used to determine competence: one was incubated for $\mathrm{I} h$ with $100 \mu \mathrm{g}$ wild-type DNA, while the other was incubated with an equivalent volume of $\mathrm{o} \cdot \mathrm{I} \times \mathrm{SSC}$ as a control. DNAase (final concentration 


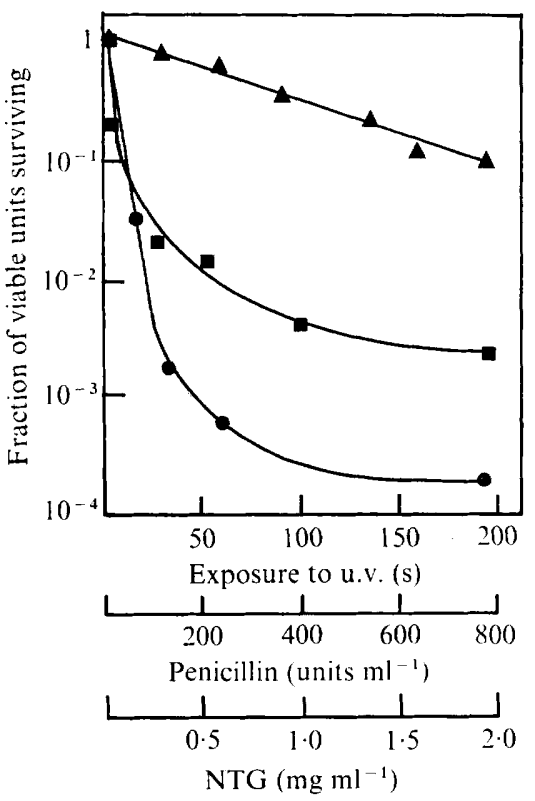

Fig. I

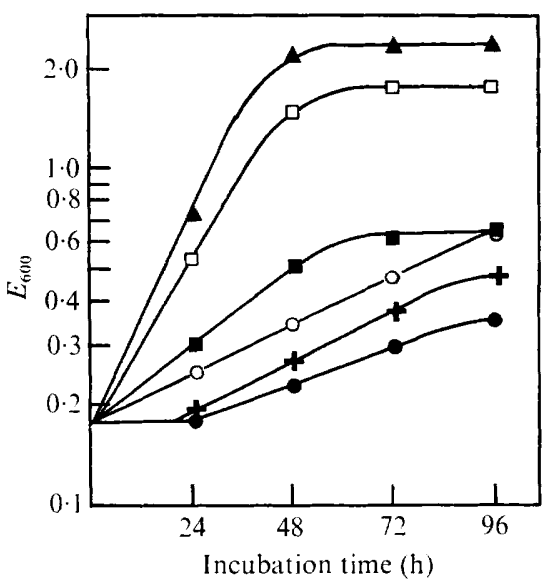

Fig. 2

Fig. 1. Viable units remaining after treatment of cultures with mutagens or penicillin: $\boldsymbol{\Delta}$, u.v. light; 9 , penicillin ( $20 \mathrm{~h}$ incubation); $\boldsymbol{\square}, \mathrm{NTG}(2 \mathrm{~h}$ incubation). Initial concentrations (viable units $\mathrm{ml}^{-1}$ ) were $4 \times 10^{8}$ (u.v.), $1 \cdot 2 \times 10^{8}$ (penicillin) and $3 \times 10^{8}$ (NTG).

Fig. 2. Growth response of wild type and isolate $3 \mathrm{~A}$ to glutamate. The growth medium was NMS/ methanol. $\boldsymbol{\Lambda}$, Wild type, all concentrations of glutamate (o to $500 \mu \mathrm{g} \mathrm{ml}^{-1}$ ). Isolate $3 \mathrm{~A}$ with glutamate at $\left(\mu \mathrm{g} \mathrm{m}^{-1}\right): \square, 500 ; \mathbf{D}, 100 ; 0,50 ;+, 10.0$, Isolate $3 \mathrm{~A}$, no additions.

$20 \mu \mathrm{g} \mathrm{ml}^{-1}$ ) was added to both samples and incubation was continued for $30 \mathrm{~min}$. The samples were then plated on selective and non-selective media. The third sample was used to determine DNA uptake. Wild-type tritiated DNA ( $10 \mu \mathrm{g} ; 20000$ c.p.m. $\mu \mathrm{g}^{-1}$; prepared by T. E. Patt, as described earlier, Patt et al., 1974) was added to the sample and incubated for I $\mathrm{h}$ before DNAase (final concentration $20 \mu \mathrm{g} \mathrm{ml}^{-1}$ ) was added and incubation was continued for $30 \mathrm{~min}$. The samples were filtered on Millipore filters and washed thoroughly with distilled water. The filters were dried, Io $\mathrm{ml}$ Bray's scintillation fluid was added (Bray, 1960) and the radioactivity was assayed in a Packard model 3375 scintillation spectrophotometer.

\section{RESULTS}

Survival curves. The sensitivity of Methylobacterium organophilum to NTG, u.v. radiation and penicillin treatment is shown in Fig. I. The NTG concentration chosen for mutagenesis was $2 \mathrm{mg} \mathrm{ml}^{-1}$ which gave $99.7 \%$ kill in $2 \mathrm{~h}$. The time of exposure chosen for u.v. mutagenesis ( $180 \mathrm{~s}$ ) gave $92 \%$ kill.

Mutant isolation. Several mutants were isolated using either NTG or u.v. mutagenesis, followed by penicillin selection. The frequency of mutant isolation was about 5 per $10^{5}$ colonies screened, except drug-resistant mutants, which appeared at a frequency of about I per $10^{7}$. The isolated mutants included auxotrophs, drug-resistant mutants and mutants unable to grow on methane or methanol, but capable of growth on glucose or succinate. Twenty-seven mutants were isolated using NTG, 24 using u.v. light. Many of the isolated mutants were considered too leaky for use in transformation studies. One of the auxo- 
Table I. Isocitrate dehydrogenase assay of isolate $3 \mathrm{~A}$ and wild type

Specific activities are expressed as nmol $\mathrm{NADP}^{+}$reduced $\min ^{-1}$ (mg protein) ${ }^{-1}$.

\begin{tabular}{|c|c|c|}
\hline \multicolumn{3}{|c|}{$\begin{array}{l}\text { Crude extract (mg protein) added } \\
\text { to reaction mixture }\end{array}$} \\
\hline $3 \mathrm{~A}$ & Wild type & Specific activity \\
\hline 0.35 & 0 & \\
\hline 0 & 0.29 & 28 \\
\hline 0.35 & 0.29 & 34 \\
\hline
\end{tabular}

Table 2. Transformation frequencies

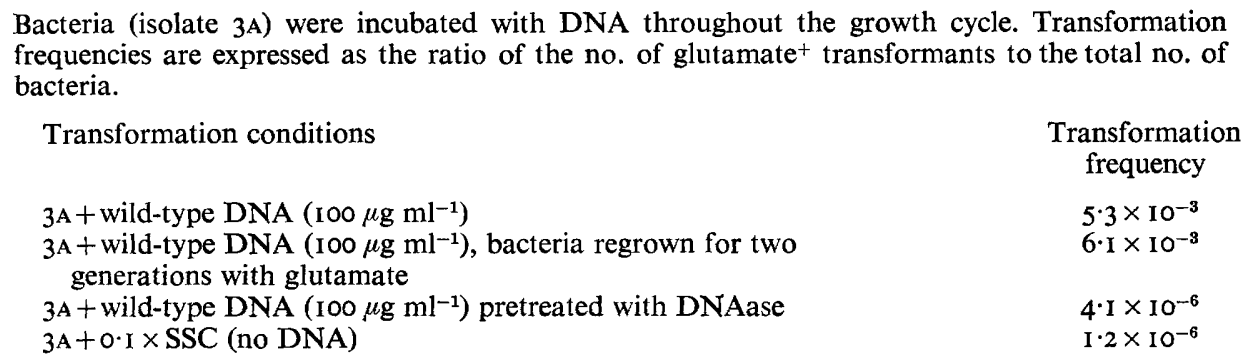

trophic isolates obtained by NTG mutagenesis was designated 3A and was chosen for further study.

Growth requirements of isolate 3A. Isolate 3A required glutamate for growth (Fig. 2). As the concentration of glutamate was increased, the growth rate and final cell densities increased to a maximum at $500 \mu \mathrm{g}$ glutamate $\mathrm{ml}^{-1}$. Higher concentrations of glutamate did not result in further growth stimulation. At its maximum growth, isolate 3A did not grow as well as the wild type. Although it grew slowly in the absence of glutamate, it formed only tiny colonies on NMS/methanol agar. Mutant colonies were readily distinguished from the larger colonies of wild-type bacteria.

Isolate $3 \mathrm{~A}$ was always filled with poly- $\beta$-hydroxybutyrate granules which permitted simple identification of the mutant and wild-type bacteria under the microscope. Because the isolate grew more slowly than the wild type, revertants, when present, outgrew the mutants after several transfers. Cultures of mutants were therefore always restreaked to obtain isolated colonies before each experiment.

Enzymic deficiency in isolate 3A. Isolate 3A lacks isocitrate dehydrogenase activity, which explains its requirement for glutamate. When an extract of the isolate was incubated with $\mathrm{NADP}^{+}$and isocitrate, there was no activity (Table I). When wild-type extract was added to the same reaction mixture, the activity observed was similar to that of the wild-type extract alone. Therefore, the lack of activity in the mutant extract was not due to the presence of an inhibitor.

Transformation frequencies. When cultures were incubated with DNA throughout their growth cycle, transformation frequencies of about $0.5 \%$ were obtained (Table 2). The frequency of transformation was increased by only $13 \%$ when transformed cultures were regrown in the presence of glutamate for two more generations; thus, phenotypic lag did not significantly influence the transformation frequency.

Cultures containing DNA which had been pretreated for 30 min with $40 \mu \mathrm{g}$ DNAase $\mathrm{ml}^{-1}$ gave frequencies of about $4 \times 10^{-6}$. The observed reversion frequency was similar. 


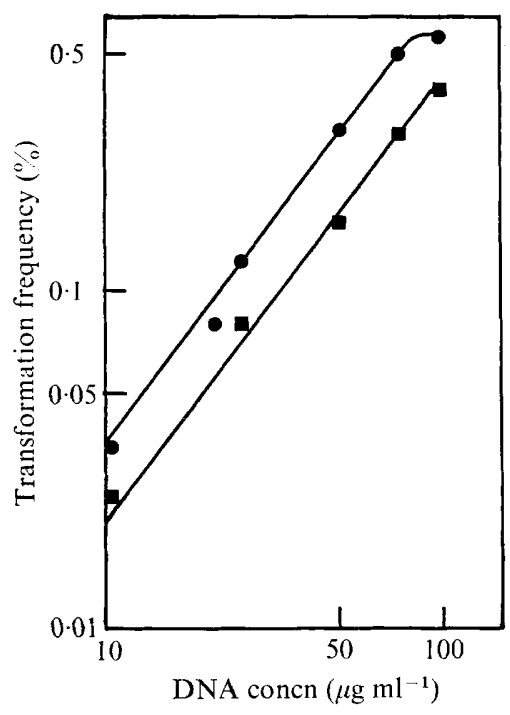

Fig. 3

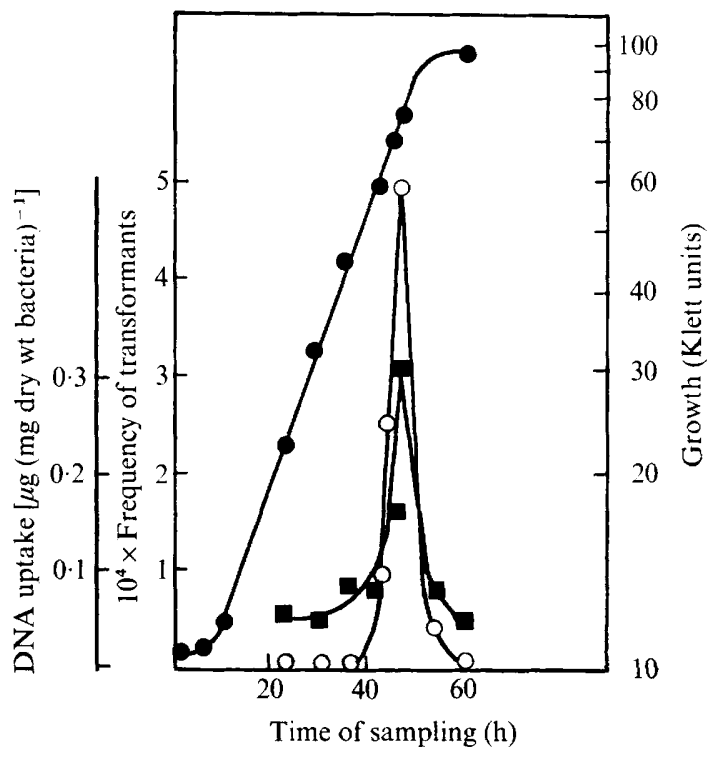

Fig. 4

Fig. 3. The dependence of transformation frequency on DNA concentration. Cultures of isolate 3A were grown to stationary phase in the presence of sheared ( $\square$ ) or unsheared (O) DNA from wild-type $M$. organophilum and portions of the culture were spread on plates of NMS/methanol or NMS/methanol plus Casamino acids.

Fig. 4. The development of competence and the uptake of DNA in isolate 3A. Samples were taken at various times during growth and incubated for $\mathrm{i} h$ with either $100 \mu \mathrm{g}$ wild-type DNA $\mathrm{ml}^{-1}$ (for determination of transformation frequencies) or $10 \mu \mathrm{g}$ wild-type $\left[{ }^{3} \mathrm{H}\right] \mathrm{DNA} \mathrm{ml} \mathrm{m}^{-1}$ (for determination of DNA uptake). , Growth; $O$, frequency of transformants; $\mathbf{a}$, DNA uptake.

$D N A$ requirement for transformation. A DNA concentration of $100 \mu \mathrm{g} \mathrm{ml}^{-1}$ was necessary for maximum transformation frequencies (Fig. 3). The use of sheared DNA resulted in slightly lower transformation frequencies. The sizes of the sheared and unsheared DNA preparations were approximately $7 \times 10^{6}$ daltons (range: $6.5 \times 10^{6}$ to $7.5 \times 10^{6}$ daltons) and $23 \times 10^{6}$ daltons (range: $19 \times 10^{6}$ to $28 \times 10^{6}$ daltons) respectively.

Deoxyribonuclease assay. DNAase activity in the culture supernatant was determined by incubating samples with tritiated DNA, precipitating with cold trichloroacetic acid, and counting the radioactivity in the precipitates. No DNAase activity was detected.

Competence and DNA uptake. The ability to be transformed occurred only in a narrow portion of the growth cycle, near the end of exponential growth (Fig. 4). DNA uptake occurred at the same point in the growth cycle as transformation. Maximum DNA uptake in the wild-type cells was only $14 \%$ of that in isolate $3 \mathrm{~A}$ and transformation of a streptomycin resistance marker into the wild type occurred at a frequency of $4 \times 10^{-5}$.

Transformation of a double mutant. A streptomycin-resistant mutant of isolate $3 \mathrm{~A}$ was isolated which grew in the presence of $50 \mu \mathrm{g}$ streptomycin $\mathrm{ml}^{-1}$ and required glutamate for growth. This double mutant was transformed to a streptomycin-resistant prototroph at a frequency of $0 \cdot 1 \%$.

\section{DISCUSSION}

Normal mutagenesis procedures resulted in the isolation of several mutants in M. organophilum. The frequency of mutant isolation was low compared to Escherichia coli (Adelberg, Mandel \& Chein Ching Chen, 1965), but higher than that reported by Williams 
\& Bainbridge (197I) for the obligate methane oxidizer, Methylococcus capsulatus. Initially high doses of NTG were used to ensure the isolation of mutants but the u.v. light procedure also resulted in the isolation of mutants. Ultraviolet light is considered the more desirable of the two mutagens because of its relative safety and the tendency of NTG to produce multiple mutations in bacteria (Guerola, Ingraham \& Cerda'-Almedo, 1971).

Isolate 3A takes up more DNA than the wild type and is transformed at higher frequencies than the wild type or other auxotrophs (unpublished results). The transformation frequencies which were obtained compare favourably with those in Bacillus (Anagnostopoulos \& Spizizen, I96I), Pneumococcus (Hotchkiss, 1954), Haemophilus (Spencer \& Herriott, I965) and Methylococcus (Williams \& Bainbridge, 197I). Competence occurs at approximately the same point in the growth cycle for all of these transformation systems. However, the DNA concentration required for maximal transformation is 10 to Ioo times higher in $M$. organophilum than in Bacillus (Anagnostopoulos \& Spizizen, I96I), Pneumococcus (Cato \& Guild, 1968), or Haemophilus (Stuy \& Stern, 1964), but is similar to that described for maximal transformation of Methylococcus (Williams \& Bainbridge, 197I).

Sheared DNA ( $16 \times 10^{6}$ daltons) gives maximal transformation in Escherichia coli, with larger and smaller DNA pieces giving lower transformation frequencies (Cosloy \& Oishi, 1973). However, in Bacillus (Morrison \& Guild, 1972), Pneumococcus (Cato \& Guild, I968) and Haemophilus (Nicolaieff \& Chevallier, I970), transformation increases with DNA size from nearly zero at DNA sizes of $0.2 \times 10^{6}$ to $0.4 \times 10^{6}$ daltons to a maximum at $20 \times 10^{6}$ to $30 \times 10^{6}$ daltons, after which it remains constant. In Bacillus and Pneumococcus the decrease in transformation frequency caused by using DNA of $7 \times 10^{6}$ daltons (the same size as the sheared DNA used in this study) was similar to that observed in $M$. organophilum transformation (Morrison \& Guild, 1972; Cato \& Guild, I968).

The absence of DNAase in the culture supernatant during growth allowed incubation of the DNA with the bacteria throughout the growth cycle so that every competent cell was exposed to DNA. When the cells were exposed to DNA for only short periods, maximum transformation frequencies were lower. This was probably due to a lack of synchrony in the development of competence and possibly to phenotypic lag.

The selective transformation of a single marker out of a doubly-marked strain, together with the results for controls without DNA or with DNAase, shows that the counted transformants are not contaminants and suggests that the transformation observed is not due to an enhancement of reversion.

We are grateful to Ellin Doyle, Andi Falck and Brian McMaster for their assistance in this work. M. O'Connor was supported by a predoctoral fellowship from the National Science Foundation. This research was also supported by the College of Agricultural and Life Sciences, University of Wisconsin, Madison, and a grant from the National Science Foundation (BMS75-I40I2).

\section{REFERENCES}

Adelberg, E. A., Mandel, M. \& Chein Ching Chen, G. (1965). Optimal conditions for mutagenesis by $N$-methyl- $N^{\prime}$-nitro- $N$-nitrosoguanidine in Escherichia coli $\mathrm{KI}$. Biochemical and Biophysical Research Communications $\mathbf{1 8}, 788-795$.

ANAGNOSTOPOUlOS, C. \& SPIzIzEN, J. (I96I). Requirements for transformation in Bacillus subtilis. Journal of Bacteriology 81, 74I-746.

Bray, G. A. (1960). A simple efficient liquid scintillator for counting aqueous solutions in a liquid scintillation counter. Analytical Biochemistry 1, 279-285.

Burton, K. (1956). A study of the conditions and mechanisms of the diphenylamine reaction for the colorimetric estimation of deoxyribonucleic acid. Biochemical Journal 62, 31 5-323. 
CATo, A. \& Guild, W. R. (I968). Transformation and DNA size. I. Activity of fragments of defined size and a fit to a random double crossover model. Journal of Molecular Biology 37, 157-1 78.

Cosloy, S. D. \& OISHI, M. (1973). The nature of the transformation process in Escherichia coli KI 2. Molecular and General Genetics 124, I-IO.

Guerola, N., Ingraham, J. L. \& Cerda'-Almedo, E. (1971). Induction of closely linked multiple mutations by nitrosoguanidine. Nature, London 230, I22-I 25.

Hanson, R. S. \& Cox, D. P. (1967). Effect of different nutritional conditions on the synthesis of tricarboxylic acid cycle enzymes. Journal of Bacteriology 93, I 777-1 787 .

Helling, R. B., Goodman, H. M. \& Boyer, H. W. (1974). Analysis of endonuclease R.EcoRI fragments of DNA from lambdoid bacteriophages and other viruses by agarose-gel electrophoresis. Journal of Virology I4, I $235-1244$.

Hotchkiss, R. D. (1954). Cyclical behaviour in pneumococcal growth and transformability occasioned by environmental changes. Proceedings of the National Academy of Sciences of the United States of Amer ca 40, 49-55.

Lowry, O. H., Rosebrough, N. J., Farr, A. L. \& Randall, R. J. (I95I). Protein measurement with the Folin phenol reagent. Journal of Biological Chemistry 193, 265-275.

Morrison, D. A. \& GuILD, W. R. (I972). Activity of deoxyibonucleic acid fragments of defined size in Bacillus subtilis transformation. Journal of Bacteriology $\mathbf{1 1 2}, 220-223$.

NicolaiefF, A. \& Chevallier, M. R. (1970). An electron microscopic study of the relation between length and transforming activity of Haemophilus influenzae. Molecular and General Genetics 109, 269-277.

O'ConNor, M. L. \& HANSON, R. S. (I975). Serine transhydroxymethylase isoenzymes from a facultative methylotroph. Journal of Bacteriology 124, 985-996.

Patt, T. E., Cole, G. C., Bland, J. \& Hanson, R. S. (1974). Isolation and characterization of bacteria that grow on methane and organic compounds as sole sources of carbon and energy. Journal of Bacteriology I20, 955-964.

Patt, T. E., Cole, G. C. \& Hanson, R. S. (1976). Methylobacterium, a new genus of facultatively methylotrophic bacteria. International Journal of Systematic Bacteriology 26, 226-229.

SPENCER, H. T. \& HerriotT, R. M. (1965). Development of competence of Haemophilus influenzae. Journal of Bacteriology 90, $9 \mathrm{I} \mathrm{I}-920$.

STUY, J. H. \& STERN, D. (1964). The kinetics of DNA uptake by Haemophilus influenzae. Journal of General Microbiology 35, 39I-400.

Williams, E. \& BAINBRIDGE, B. W. (I97I). Genetic transformation in Methylococcus capsulatus. Journal of Applied Bacteriology 34, 683-687. 